\title{
Control of Listeria monocytogenes growth in soft cheeses by bacteriophage P100
}

\author{
Elaine Nóbrega Gibson Silva ${ }^{1}$, Ana Cláudia Leite Figueiredo ${ }^{2}$, \\ Fernanda Araújo Miranda ${ }^{2}$, Rogeria Comastri de Castro Almeida ${ }^{2}$ \\ ${ }^{1}$ Departamento de Análises Bromatológicas, Faculdade de Farmácia, \\ Universidade Federal da Bahia, Salvador, BA, Brazil. \\ ${ }^{2}$ Departamento de Ciência dos Alimentos, Escola de Nutrição, \\ Universidade Federal da Bahia, Salvador, BA, Brazil.
}

Submitted: February 23, 2012; Approved: September 9, 2013.

\begin{abstract}
The purpose of this study was to determine the effect of bacteriophage P100 on strains of Listeria monocytogenes in artificially inoculated soft cheeses. A mix of $L$. monocytogenes $1 / 2 \mathrm{a}$ and Scott A was inoculated in Minas Frescal and Coalho cheeses (approximately $10^{5} \mathrm{cfu} / \mathrm{g}$ ) with the bacteriophage added thereafter $\left(8.3 \times 10^{7} \mathrm{PFU} / \mathrm{g}\right)$. Samples were analyzed immediately, and then stored at $10{ }^{\circ} \mathrm{C}$ for seven days. At time zero, 30 min post-infection, the bacteriophage P100 reduced $L$. monocytogenes counts by $2.3 \log$ units in Minas Frescal cheese and by 2.1 log units in Coalho cheese, compared to controls without bacteriophage. However, in samples stored under refrigeration for seven days, the bacteriophage P100 was only weakly antilisterial, with the lowest decimal reduction (DR) for the cheeses: $1.0 \mathrm{log}$ unit for Minas Frescal and $0.8 \log$ units for Coalho cheese. The treatment produced a statistically significant decrease in the counts of viable cells $(p<0.05)$ and in all assays performed, we observed an increase of approximately one log cycle in the number of viable cells of L. monocytogenes in the samples under refrigeration for seven days. Moreover, a smaller effect of phages was observed. These results, along with other published data, indicate that the effectiveness of the phage treatment depends on the initial concentration of $L$. monocytogenes, and that a high concentration of phages per unit area is required to ensure sustained inactivation of target pathogens on food surfaces.
\end{abstract}

Key words: food safety, Listeria, biocontrol, bacteriophage, cheese.

\section{Introduction}

Minas Frescal and Coalho are very popular traditional cheeses in Brazil. They are classified as soft cheeses and produced by enzymatic coagulation of cow's milk with rennet and/or other appropriate enzymes, and are either complemented or not by the action of specific lactic bacteria.

Reports have indicated that these food products are susceptible to recontamination with $L$. monocytogenes after heat processing (Cox, 1989; Rocourt and Cossart, 1997). Because L. monocytogenes is capable of growing at refrigeration temperatures, antimicrobial strategies to overcome the tolerance of this microorganism for low temperatures are essential, and the industry has sought more effective methods to combat this pathogen.
Despite recent advancements in technologies to control pathogen in foods, consumers have been searching for "natural" foods; i.e., foods submitted to less aggressive treatments and free of chemical preservatives (Pranoto et al., 2005). Among these substances, we found the bacteriophages, which are viruses that infect only bacteria and do not cause changes in the food flavor, color or other physical properties (Pao et al., 2004).

Bacteriophages are naturally occurring viruses that are suitable candidates for the environmentally friendly biocontrol of pathogens (Guenther et al., 2009). They do not have their own metabolism, but rely on host bacteria to multiply and exhibit narrow host ranges, usually targeting specific strains (Guenther et al., 2009). 
Phages are omnipresent and accidentally, yet regularly, consumed through ingestion of water and food. For this reason, they are presumed to be safe, since undesirable effects have not been reported. Their benign nature and specificity make them excellent tools for food safety applications (Mahony et al., 2010).

Recently the USFDA announced that it had approved the use of a bacteriophage preparation made from six individually purified bacteriophages to be used on ready-to-eat meat and poultry products as an antimicrobial agent against L. monocytogenes (EBI Food Safety, 2007). The commercial product named LISTEX_P100 was approved as a food biopreservative and granted GRAS (Generally Recognized as Safe) status (Food and Drug Administration, 2006).

The recent approval for the use of phages on $L$. monocytogenes for food safety purposes has increased the impetus for phage research to uncover phage-mediated applications with activity against other food pathogens (Mahony et al., 2010).

Considering that the contamination of dairy products (especially soft cheeses) by Listeria spp. is most often caused by faulty or insufficiently sanitized equipment (Taylor et al., 1981), factory-specific flora could be found. Although many foods can serve as vehicles for this pathogen, Listeria is often isolated from ready-to-eat (RTE) foods, such as milk and cheeses; cold-cut meats; smoked fish; seafood; and vegetables (Ryser and Marth, 2006). Of particular concern is the fact that these foods are consumed directly, without a final bactericidal processing step.

The present study was undertaken to evaluate the inhibitory effect of the bacteriophage P100 on strains of $L$. monocytogenes in artificially inoculated Minas Frescal and Coalho cheeses at time zero, 30 min post-infection, and after seven days under refrigeration.

\section{Materials and Methods}

\section{Cheeses}

Minas Frescal is classified as a soft cheese with very high moisture, raw mass and a soft or lightly acidic flavor. Coalho is a curdle cheese, classified as has middle range humidity at half-cooking or cooking mass.

The distinctive characteristics of the elaboration process of the cheeses include approximately $40 \mathrm{~min}$ of coagulation, cutting and mixing of the mass, partial removal of the serum, heating of the mass with hot water or indirect steam (Coalho cheese) until attainment of half-cooking $\left(45^{\circ} \mathrm{C}\right)$ or cooking mass (between 45 and $55^{\circ} \mathrm{C}$ ), addition of salt (sodium chloride) to the mass, pressing, drying, packaging and sale. These products should be stored between 1.0 and $10{ }^{\circ} \mathrm{C}$, and consumed within seven days after opening (Brasil, 1997; Brasil, 2001).

\section{Bacterial strains, media and culture conditions}

The bacteria used in this study were as follows: a Listeria monocytogenes (serotype 1/2a) isolated from raw milk in a cheese manufacturing plant of Bahia state, Brazil; Listeria monocytogenes Scott A - ATCC 15313 (serotype 4b); Listeria ivanovii WSLC 3009 (SLCC 4769); and bacteriophage P100 (LISTEX P100), provided by EBI Food Safety (Wageningen, The Netherlands) (Food and Drug Administration, 2006). L. ivanovii was used as a helper strain to determine the titer of the P100 bacteriophage (Loessner and Busse, 1990; Carlton et al., 2005).

The cultures of $L$. monocytogenes and L. ivanovii were stored in Hogness medium $\left(1.3 \mathrm{mM} \mathrm{K}_{2} \mathrm{HPO}_{4} .3 \mathrm{H}_{2} \mathrm{O}\right.$ $1.3 \mathrm{mM} \mathrm{KH} \mathrm{KO}_{4}, 2.0 \mathrm{mM}$ citrate-Na.2 $\mathrm{H}_{2} \mathrm{O}, 1.0 \mathrm{mM}$ $\mathrm{MgSO}_{4} .7 \mathrm{H}_{2} \mathrm{O}$, and $4.4 \%(\mathrm{v} / \mathrm{v})$ glycerol) and frozen at $-80{ }^{\circ} \mathrm{C}$. Before use, L. monocytogenes cultures were activated in tryptic soy broth (Difco, Detroit, MI, USA) supplemented with $0.5 \%(\mathrm{w} / \mathrm{v})$ of yeast extract (Difco, Detroit, MI, USA) (TSB-YE) and incubated at $35^{\circ} \mathrm{C}$ overnight in a shaker (Cientec, model CT 712, Brazil) at $150 \mathrm{rpm}$. $L$. ivanovii culture was grown overnight at $30^{\circ} \mathrm{C}$ in a half-concentrated brain-heart infusion broth (BHI, 1/2 v/v, Difco, Detroit, MI, USA) with the $\mathrm{NaCl}$ concentration adjusted to $5 \mathrm{~g} / \mathrm{L}$.

In all experiments, the top layer agar (semi-soft agar or overlay agar) was prepared by adding $0.4 \%(\mathrm{w} / \mathrm{v})$ of agar to BHI. To improve the visualization of bacteriophage plaques, $0.75 \%(\mathrm{w} / \mathrm{v})$ of glycine (Sigma Aldrich - Poole, United Kingdom) was added to the top layer of agar (Lillehaug, 1997). Appropriate bacterial dilutions were made in lambda buffer (6 mM Tris buffer, $\mathrm{pH} 7.2 ; 10 \mathrm{mM} \mathrm{Mg}$ $\left(\mathrm{SO}_{4}\right)_{2} .7 \mathrm{H}_{2} \mathrm{O}$; and $50 \mu \mathrm{g} / \mathrm{mL}$ gelatin).

Bacterial survival following treatment with the bacteriophage P100 or no treatment was determined by colony-forming units $(\mathrm{CFU} / \mathrm{g})$ on lithium chloride-phenylethanol-moxalactam (LPM, Difco, Detroit, MI, USA) agar with $0.1 \%$ of esculin and $0.05 \%$ of ferric citrate ammoniac.

\section{Titration of P100 bacteriophage}

The titer of the P100 was determined according to a protocol suggested by EBI Food Safety (personal communication). For this protocol, serial dilutions of the bacteriophage suspension in a lambda buffer were made, and $100 \mu \mathrm{L}$ of each dilution were mixed into $3.5 \mathrm{~mL}$ of the molten overlay agar cooled to $45^{\circ} \mathrm{C}$, which contained $150 \mu \mathrm{L}$ of log-phase L. ivanovii culture grown overnight at $30^{\circ} \mathrm{C}$ in a $1 / 2$ strength $\mathrm{BHI}$. This mixture was poured onto $\mathrm{BHI}$ agar $\left(1.2 \% \mathrm{w} / \mathrm{v}\right.$ agar) plates and incubated at $30{ }^{\circ} \mathrm{C}$ for $20-24 \mathrm{~h}$. Plaques were counted, and the titer was determined in plaque-forming units (PFU).

To recover the bacteriophage from food without $L$. monocytogenes (phage control), the sample was diluted in lambda buffer, and an aliquot of $100 \mu \mathrm{L}$ was incorporated into $3.5 \mathrm{~mL}$ of the molten overlay agar cooled to $45^{\circ} \mathrm{C}$, 
which contained $150 \mu \mathrm{L}$ of $L$. ivanovii (helper strain). As mentioned above, the mixture was poured onto $\mathrm{BHI}$ agar $\left(1.2 \% \mathrm{w} / \mathrm{v}\right.$ agar) plates and incubated at $30^{\circ} \mathrm{C}$ for $20-24 \mathrm{~h}$. Plaques were counted, and the titer was determined as plaque forming units $(\mathrm{PFU} / \mathrm{g})$.

\section{Preparation of bacterial inoculums}

L. monocytogenes $1 / 2 \mathrm{a}$ and Scott A (serotype $4 \mathrm{~b}$ ) were cultured by loop inoculation of $10 \mathrm{~mL}$ volumes of tryptic soy broth containing $0.5 \%(\mathrm{w} / \mathrm{v})$ yeast extract (TSB-YE), followed by incubation at $35^{\circ} \mathrm{C}$ for $18-20 \mathrm{~h}$ in a shaker at $150 \mathrm{rpm}$. The cell suspensions were transferred to sterile Eppendorf tubes, and inoculum levels were confirmed by the surface plating of duplicate samples onto LPM agar. The plates were incubated at $35^{\circ} \mathrm{C}$ for $24 \mathrm{~h}$ before the colony counts were obtained. Cell suspensions were diluted in an appropriate amount of $0.1 \%(\mathrm{w} / \mathrm{v})$ of peptone water to yield a cell number of $10^{5} \mathrm{cfu} / \mathrm{mL}$, and were used immediately for sample inoculation.

\section{Sample inoculation and treatment application}

Minas Frescal and Coalho cheeses were purchased at a local supermarket in Salvador, Bahia, Brazil. The samples were transported to the laboratory in insulated, iced containers for analysis. After aseptically removing the package under a class II biosafety cabinet (Labconco, model 36210 class BII, Kansas City, MO, USA), four samples with $30 \mathrm{~g}$ of Minas Frescal cheese and four samples with $30 \mathrm{~g}$ of Coalho cheese were transferred to a bag mixer. Two samples of each cheese were designated as time zero samples and two were designated as seven-day samples. All samples were inoculated separately with $1 \mathrm{~mL}$ of the mixture of L. monocytogenes $1 / 2 \mathrm{a}$ and Scott A (approximately $10^{5} \mathrm{cfu} / \mathrm{mL}$ ). Inoculated samples were homogenized gently by manual shaking to ensure an even distribution of organisms, and were air dried under a class II biosafety cabinet for $30 \mathrm{~min}$ at $21^{\circ} \mathrm{C}$ to allow the attachment of bacteria into the cheese (Singh et al., 2002).

Two samples of each cheese (one time zero sample and one seven-day sample) were treated with $1 \mathrm{~mL}$ volumes of the P100 bacteriophage $\left(2.5 \times 10^{9} \mathrm{PFU} / \mathrm{mL}\right)$ to yield a final application dose of $8.3 \times 10^{7} \mathrm{PFU} / \mathrm{g}$, and two of the samples were designated as controls (one for time zero and one for seven days). For the controls, $1 \mathrm{~mL}$ of saline solution $(0.85 \% \mathrm{w} / \mathrm{v} \mathrm{NaCl})$ was added to the two samples. The samples were kept inside a stomacher bag, sealed and incubated at room temperature $\left(21^{\circ} \mathrm{C}\right)$ for $30 \mathrm{~min}$ to allow for infection. One of the samples was immediately subjected to L. monocytogenes enumeration on LPM agar, and the other was stored at $10^{\circ} \mathrm{C}$ for seven days.

For enumeration of L. monocytogenes, each $30 \mathrm{~g}$ portion was added to $270 \mathrm{~mL}$ of lambda buffer with $0.01 \%$ $(\mathrm{w} / \mathrm{v})$ of Tween-80 and homogenized in a stomacher (ITR, model 1204, series 126, Esteio, RS, Brazil, 240 bpm) for $2 \mathrm{~min}$. Serial dilutions were made in the same solution without Tween-80, and the solutions were spread onto duplicate LPM plates, which were incubated at $35^{\circ} \mathrm{C}$ for $48 \mathrm{~h}$. Bacterial survival following treatment with P100 bacteriophage or no treatment (control) was determined by measuring colony-forming units (CFU).

\section{Investigation of Listeria spp. in Minas Frescal and Coalho cheeses}

The cheese samples were analyzed for the presence or absence of Listeria spp. before inoculation with $L$. monocytogenes strains by streaking Half Fraser enrichment broth (Difco, Detroit, MI, USA) on LPM agar (DIFCO) plates to test for the presence of typical Listeria spp. colonies. One $L$. monocytogenes positive control $(L$. monocytogenes Scott A, ATCC 15313) and one uninoculated media negative control were used for each set of concurrently analyzed samples.

\section{Statistical analysis}

To investigate the effectiveness of bacteriophage $\mathrm{P} 100$ in the elimination of $L$. monocytogenes $1 / 2 \mathrm{a}$ and Scott A, bacterial counts were always determined in duplicate, and all of the experiments described here were independently performed three times. All counts of bacteria $(\mathrm{cfu} / \mathrm{g})$ recovered from Minas Frescal and Coalho cheeses were converted to logarithms before computing means and standard deviations. The decimal reduction (DR) of the population of the bacteria was calculated by the difference between the counts obtained in the control and treatment preparations. Log values of zero were assumed for samples in which L. monocytogenes was not detected $(<2 \log$ $\mathrm{cfu} / \mathrm{g}$ ). The data were subjected to the Statistical Analysis System of variance and Tukey's multiple range (Software ASSISTAT, version 7.6 beta, 2011) to determine if significant differences $(\mathrm{p}<0.05)$ in mean log values existed in the populations of $L$. monocytogenes between the treatment groups.

\section{Results}

The microbiological evaluation of Minas Frescal and Coalho cheeses before inoculation with $L$. monocytogenes revealed an absence of Listeria spp. in the samples investigated.

The effect of bacteriophage P100 (LISTEX P100) on the survival of $L$. monocytogenes strains was evaluated by measurement of viable cell counts and the innoculum used was $10^{5} \mathrm{cfu} / \mathrm{mL}(5.0 \log \mathrm{cfu} / \mathrm{mL})$, approximately. The results obtained for Minas Frescal and Coalho cheeses are presented in Tables 1 and 2, respectively. The treatment decreased the cell numbers of $L$. monocytogenes at time zero, 30 min post-infection, and at seven days at $10^{\circ} \mathrm{C}$, relative to cheeses containing no phages. The results indicate that the P100 bacteriophage may reduce the number of Listeria cells in soft cheeses. 
Table 1 - Reduction in the viable counts of Listeria monocytogenes in Minas Frescal cheese by bacteriophage P100, in a mix of 1/2a and Scott A serovars, at zero and seven days $\left(10^{\circ} \mathrm{C}\right)$.

\begin{tabular}{|c|c|c|c|c|c|c|}
\hline \multirow[t]{3}{*}{ Experiment } & \multicolumn{6}{|c|}{ Listeria monocytogenes $\left(\log _{10} \mathrm{cfu} / \mathrm{g}\right)$} \\
\hline & \multicolumn{3}{|c|}{ Time zero } & \multicolumn{3}{|c|}{ Seven days } \\
\hline & Control & Treatment $\mathrm{t}^{\mathrm{b}}$ & $\mathrm{DR}^{\mathrm{c}}$ & Control & Treatment $^{\mathrm{b}}$ & $\mathrm{DR}^{\mathrm{c}}$ \\
\hline 1 & 5.9 & 3.6 & 2.3 & 6.6 & 5.6 & 1.0 \\
\hline 2 & 6.0 & 3.5 & 2.5 & 6.5 & 5.3 & 1.2 \\
\hline 3 & 5.1 & 3.4 & 1.7 & 6.5 & 5.6 & 0.9 \\
\hline $\operatorname{Mean}^{\mathrm{a}}$ & $5.8 \pm 0.4^{\mathrm{A}^{*}}$ & $3.5 \pm 0.08^{\mathrm{B}}$ & 2.3 & $6.5 \pm 0.04^{\mathrm{A}}$ & $5.5 \pm 0.14^{\mathrm{B}}$ & 1.0 \\
\hline
\end{tabular}

${ }^{\mathrm{a}}$ Mean \pm standard deviation. ${ }^{\mathrm{b}}$ Bacteriophage P100 (title $2.5 \times 10^{9} \mathrm{PFU} / \mathrm{mL}$ ). ${ }^{\mathrm{c}}$ Decimal reduction. *Means followed by different letters are significantly different by Tukey's test $(\mathrm{p}<0.05)$.

Table 2 - Reduction in the viable counts of Listeria monocytogenes in Coalho cheese by bacteriophage P100, in a mix of 1/2a and Scott A serovars, at zero and seven days $\left(10^{\circ} \mathrm{C}\right)$.

\begin{tabular}{|c|c|c|c|c|c|c|}
\hline \multirow[t]{3}{*}{ Experiment } & \multicolumn{6}{|c|}{ Listeria monocytogenes $\left(\log _{10} \mathrm{cfu} / \mathrm{g}\right)$} \\
\hline & \multicolumn{3}{|c|}{ Time zero } & \multicolumn{3}{|c|}{ Seven days } \\
\hline & Control & Treatment ${ }^{\mathrm{b}}$ & $\mathrm{DR}^{\mathrm{c}}$ & Control & Treatment $^{\mathrm{b}}$ & $\mathrm{DR}^{\mathrm{c}}$ \\
\hline 1 & 5.1 & 3.1 & 2.1 & 6.5 & 5.6 & 0.8 \\
\hline 2 & 5.6 & 3.6 & 2.3 & 6.6 & 5.7 & 1.1 \\
\hline 3 & 5.6 & 3.3 & 1.7 & 6.4 & 5.8 & 0.8 \\
\hline Mean $^{\mathrm{a}}$ & $5.5 \pm 0.2^{\mathrm{A}^{*}}$ & $3.4 \pm 0.2^{\mathrm{B}}$ & 2.1 & $6.5 \pm 0.08^{\mathrm{A}}$ & $5.7 \pm 0.08^{\mathrm{B}}$ & 0.8 \\
\hline
\end{tabular}

${ }^{\mathrm{a}}$ Mean \pm standard deviation. ${ }^{\mathrm{b}}$ Bacteriophage P100 (title $2.5 \times 10^{9} \mathrm{PFU} / \mathrm{mL}$ ). ${ }^{\mathrm{c}}$ Decimal reduction. *Means followed by different letters are significantly different by Tukey's test $(\mathrm{p}<0.05)$.

A mean reduction of greater than 2.0 log cycles in viable counts was observed at time zero: $6.6 \times 10^{5}$ to $3.2 \times 10^{3}$ $\mathrm{cfu} / \mathrm{g}$ for Minas Frescal cheese, and $2.9 \times 10^{5}$ to $2.3 \times 10^{3}$ $\mathrm{cfu} / \mathrm{g}$ for Coalho cheese. However, in samples stored under refrigeration for seven days, the bacteriophage P100 was only weakly antilisterial, with the lowest decimal reduction (DR) for the cheeses: approximately $1.0 \log$ unit $\left(3.4 \times 10^{6}\right.$ to $\left.3.5 \times 10^{5} \mathrm{cfu} / \mathrm{g}\right)$ for Minas Frescal and $0.8 \log$ units $(3.2 \mathrm{x}$ $10^{6}$ to $4.7 \times 10^{5} \mathrm{cfu} / \mathrm{g}$ ) for Coalho. In untreated samples, the numbers of L. monocytogenes exceeded $6.0 \mathrm{log} \mathrm{cfu} / \mathrm{g}$.

For both cheeses, the statistical analysis indicated a significant difference $(p<0.05)$ between the treated samples and control, at zero and seven days (Tables 1 and 2).

The results obtained from the control samples of bacteriophage alone indicate that the concentration of $\mathrm{P} 100$ was lowest after seven days of storage: mean value of $4.4 \mathrm{x}$ $10^{7} \mathrm{PFU} / \mathrm{g} \pm 0.12$ at zero day and $3.0 \times 10^{4} \mathrm{PFU} / \mathrm{g} \pm 0.13$ at seven days for Minas Frescal cheese, and $4.8 \times 10^{8} \mathrm{PFU} / \mathrm{g} \pm$ 0.05 at zero day and $4.2 \times 10^{5} \mathrm{PFU} / \mathrm{g} \pm 0.13$ at seven days for Coalho cheese.

\section{Discussion}

Previous studies have demonstrated that cheese is a potential reservoir for L. monocytogenes because of the higher availability of nutrients on cut cheese surfaces and the greater potential for contamination due to the increased amount of handling (James et al., 1983; Schlech et al., 1983; Beckers et al., 1987; Farber et al., 1987; Pintado et al., 2004; Makino et al., 2005;). In our country, the incidence of $L$. monocytogenes in three cheese manufacturing plants from the northeastern region of Sao Paulo was evaluated recently, and L. monocytogenes was isolated from two of the three plants. L. monocytogenes was also isolated from the surface of Prato cheese and brine from one of the evaluated plants. Serotype $4 \mathrm{~b}$ predominated in the plants studied, and these results indicate the need of control strategies to prevent the dispersion of $L$. monocytogenes in the environment of cheese manufacturing plants (Barancelli et al., 2011).

This paper reports valuable information about the antimicrobial properties of bacteriophage $\mathrm{P} 100$ against two serotypes of L. monocytogenes. Antimicrobial effects are measured in terms of decimal reduction, which allows for comparisons between different studies.

Our results have demonstrated that the bacteriophage P100 reduced the population of L. monocytogenes in Minas Frescal and Coalho cheeses by 2.3 and 2.1 log cycles, respectively, following the addition of the phage. These results are in accordance with Leverentz et al. (2003), who reported that lytic $L$. monocytogenes-specific phages reduced L. monocytogenes populations on honeydew melons by 2.0 to $4.6 \log$ units relative to the control, and Rossi et al. 
(2011) who showed that the bacteriophage P100 reduced L. monocytogenes counts by $2.5 \log$ units in Brazilian fresh sausage.

According to Leverentz et al. (2003), the effectiveness of the phage treatment depended on the initial concentration of L. monocytogenes. Similarly, Bigot et al. (2011) reported that a bacteriophage similar to phage A511 prevented the growth of $L$. monocytogenes on the surface of a vacuum-packed, ready-to-eat chicken breast roll. In that study, the bacteria were present at approximately twice its concentration for $7 \mathrm{~h}$, and the authors observed an immediate $2.5 \log _{10} \mathrm{cfu} \mathrm{cm}^{-2}$ reduction in pathogen concentration following the addition of phages, and then re-growth.

Carton et al. (2005) contaminated cheeses with low concentrations of L. monocytogenes at the beginning of the ripening period, and $\mathrm{P} 100$ was applied to the surface during the rind washings. Depending on the time points, frequency and dose of phage applications, the authors were able to obtain a significant reduction (at least $3.5 \log$ units) or complete eradication of Listeria viable counts.

Soni and Nannapaneni (2010) also investigated the effectiveness of bacteriophage P100 against $L$. monocytogenes serotypes $1 / 2 \mathrm{a}$ and $4 \mathrm{~b}$ on the surface of raw salmon fillet tissue in a broth model system. According to the authors, phage P100 completely inhibited L. monocytogenes growth at $4{ }^{\circ} \mathrm{C}$ for 12 days, at $10^{\circ} \mathrm{C}$ for 8 days, and at $30^{\circ} \mathrm{C}$ for 4 days, and at phage concentrations of $10^{4}, 10^{6}$, and $10^{8}$ $\mathrm{PFU} / \mathrm{mL}$. However, a higher phage concentration of $10^{8}$ $\mathrm{PFU} / \mathrm{g}$ was required to yield $1.8,2.5$, and $3.5 \mathrm{log} \mathrm{cfu} / \mathrm{g}$ reductions of L. monocytogenes from initial loads of 2.0, 3.0, and $4.5 \log \mathrm{cfu} / \mathrm{g}$ at 4 or $22{ }^{\circ} \mathrm{C}$, respectively.

One study reported that the reduction in L. monocytogenes counts on raw catfish fillet tissue with the P100 phage $\left(2 \times 10^{7} \mathrm{PFU} / \mathrm{g}\right)$ was $1.4-2.0 \mathrm{log} \mathrm{cfu} / \mathrm{g}$ at $4{ }^{\circ} \mathrm{C}, 1.7-2.1$ $\log \mathrm{cfu} / \mathrm{g}$ at $10^{\circ} \mathrm{C}$, and 1.6-2.3 log cfu/g at room temperature $\left(22^{\circ} \mathrm{C}\right.$ ). The phage contact time of $30 \mathrm{~min}$ (the same time used in our study) was adequate to yield a greater than $1.0 \mathrm{log} \mathrm{cfu} / \mathrm{g}$ reduction in L. monocytogenes, whereas a 15 min contact time with phage yielded less than a $1.0 \mathrm{log}$ cfu/g bacterial load reduction (Soni et al., 2010).

In all assays performed, we observed an increase of approximately $1.0 \mathrm{log}$ cycle in the number of viable cells of L. monocytogenes in the samples under refrigeration for seven days. Moreover, a lesser effect of phages was observed. This result demonstrated the influence of the storage of the cheeses.

Rossi et al. (2011) and Bigot et al. (2011) also demonstrated that the populations of $L$. monocytogenes increased over the storage. According to Bigot et al. (2011), the re-growth of L. monocytogenes in a ready-to-eat chicken breast roll occurred such that the concentration after $24 \mathrm{~h}$ of incubation was similar in both control and phage-treated cultures. However, the authors demonstrated that at a temperature in which a chilled food might be stored $\left(5{ }^{\circ} \mathrm{C}\right)$, bacterial regrowth was prevented over a 21 -day incubation.

Our results indicate that there are phages remaining in the samples after seven days (shelf life of the cheeses after opening), but the concentration of phage particles was insufficient to infect Listeria cells present and to show the same effect demonstrated $30 \mathrm{~min}$ post-infection (time zero).

The successful phage infection and subsequent killing of the host cells is strongly dependent on the environmental conditions, i.e., the type of food and its specific matrix (Guenther et al., 2009). According to the authors, the proportion of bacterial cells that can be infected depends on several parameters: First, the binding of phages to their receptors on the bacterial surfaces is influenced by intrinsic factors, such as ionic strength, $\mathrm{pH}$, and substances, which may interfere with this process. These parameters are largely defined by the food itself and may change during the production, ripening, or storage of the items. Second, the concentration of phage at the time of application is crucial for efficacy, i.e., applying more phage generally resulted in greater inactivation.

\section{Conclusions}

Our findings demonstrate the efficacy of bacteriophage $\mathrm{P} 100$ for rapid reduction of L. monocytogenes on soft cheeses followed by a weakly antilisterial effect after storage. These results, along with other published data, indicate that the effectiveness of the phage treatment depends on the initial concentration of L. monocytogenes and that a high concentration of phages per unit area is required to ensure sustained inactivation of target pathogens on food surfaces.

\section{Acknowledgments}

The authors thank CAPES for scholarship support.

\section{References}

Barancelli GV, Camargo TM, Reis CM, Porto E, Hofer E, Oliveira CA (2011) Incidence of Listeria monocytogenes in cheese manufacturing plants from the northeast region of Sao Paulo, Brazil. J Food Prot 74:816-819.

Beckers HJ, Soentero PSS, Delfou-Van Asch EHM (1987) The occurrence of Listeria monocytogenes in soft cheeses and raw milk and its resistance to heat. Int J Food Microbiol 4:249-256.

Bertin A, Frutos M, Letellier L (2011) Bacteriophage-host interactions leading to genome internalization. Curr Opin Microbiol 14:492-496.

Bigot B, Lee W-J, Mcintyre L, Wilson T, Hudson JA, Billington C, Heinemann JA (2011) Control of Listeria monocytogenes growth in a ready-to-eat poultry product using a bacteriophage. Food Microbiol 28:1448-52.

Brasil (1997) Portaria no 352 de 4 de setembro de 1997. Regulamento técnico para fixação de identidade e qualidade de queijo Minas Frescal. Diário Oficial da República Federa- 
tiva do Brasil, Poder Executivo, Brasília, DF, Seção 1, p. 19684.

Brasil (2001) Instrução Normativa nº 30 de 26 de julho de 2001. Regulamento Técnico de Identidade e Qualidade de Queijo de Coalho. Diário Oficial da República Federativa do Brasil, Poder Executivo, Brasília, DF, Seção 1, p. 14-15.

Carlton RM, Noordman WH, Biswas B, Meester ED, Loessner MJ (2005) Bacteriophage P100 for control of Listeria monocytogenes in foods: Genome sequence, bioinformatic analyses, oral toxicity study, and application. Regul Toxicol Pharmacol 43:301-312.

Cox JL (1989) A perspective of listeriosis. Food Tech 43:52-59.

EBI Food Safety (2007) FDA and USDA extend GRAS approval for LISTEX for all food products. News 2007, July, 2007. Available http://www.ebifoodsafety.com/en/news-2007.aspx. Accessed January 10th, 2009.

Farber JM, Johnson MA, Purvis U, Loit A (1987) Surveillance of soft and semi-soft cheese for the presence of Listeria spp. Int J Food Microbiol 5:157-163.

Food and Drug Administration (2006) FDA approval of Listeria-specific bacteriophage preparation on ready-to-eat (RTE) meat and poultry products. Available at http://www.cfsan.fda.gov/FDACenter 2006/, Accessed October 10, 2008 (Online).

Guenther S, Huwyler D, Richard S, Loessner MJ (2009) Virulent bacteriophage for efficient biocontrol of Listeria monocytogenes in ready-to-eat foods. Appl Environ Microbiol 75:93-100.

James SM, Fannin SL, Agree BA, Hall B, Parker E, Vogt J, Run G, Williams J, Lieb L, Salminen C, Prendergast T, Werner SB, Chin J (1983) Listeriosis outbreak associated with Mexican-style cheese: California. MMWR Morb Mort Wkly Rep 34:357-359.

Leverentz B, Conway WS, Camp MJ, Janisiewicz WJ, Abuladze T, Yang M, Saftner R, Sulakvelidze A (2003) Biocontrol of Listeria monocytogenes on fresh-cut produce by treatment with lytic bacteriophages and a bacteriocin. Appl Environ Microbiol 69:4519-4526.

Lillehaug D (1997) An improved plaque assay for poor plaqueproducing temperate lactococcal bacteriophages. J Appl Microbiol 83:85-90.

Loessner MJ, Busse M (1990) Bacteriophage typing of Listeria species. Appl Environ Microbiol 56:1912-1918.

Mahony J, Auliffe OM, Ross RP, Van Sinderen D (2010) Bacteriophages as biocontrol agents of food pathogens. Curr Opin Biotechnol 22:1-7.
Makino SI, Kawamoto K, Takeshi K, Okada Y, Yamasaki M, Yamamoto S, Igimi S (2005) An outbreak of food-borne listeriosis due to cheese in Japan, during 2001. Int J Food Microbiol, Amsterdam 104:189-196.

Pao S, Randolph SP, Westbrook EW, Shen H (2004) Use of bacteriophages to control Salmonella in experimentally contaminated sprout seeds. J Food Sci 69:127-130.

Pintado CMBS, Oliveira A, Pampulha ME, Ferreira MASS (2004) Prevalence and characterization of Listeria monocytogenes isolated from soft cheese. Food Microbiol, Amsterdam 21:213-216.

Pranoto Y, Rakshit SK, Salokhe VM (2005) Enhancing antimicrobial activity of chitosan films by incorporating garlic oil, potassium sorbate and nisin. Lebensmittel Wissenschaft and Technologie 38:859-865.

Rocourt J, Cossart P (1997) Listeria monocytogenes. In: Beuchat LR, Doyle MP, Montville TJ (Eds.), Food Microbiology: Fundamentals and Frontiers. ASM Press, Washington D.C., pp. 337-352.

Rossi LPR, Almeida RCC, Lopes LS, Figueiredo ACL, Ramos MPP, Almeida PF (2011) Occurrence of Listeria spp. in Brazilian fresh sausage and control of Listeria monocytogenes using bacteriophage P100. Food Control 22:954-958

Ryser ET, Marth EH Eds. (2006) Listeria, listeriosis and food safety. 3rd edition, Taylor and Francis, Boca Raton, Florida.

Schlech WF, Lavigne III PM, Bortolussi RA, Allen AC, Haldane EV, Wort AJ, Hightower AW, Johnson SE, King SH, Nichols ES, Broome CV (1983) Epidemic listeriosisevidence for transmission by food. New England Journal of Medicine 308:203-206.

Singh N, Singh RK, Bhunia AK, Stroshine RL (2002) Effect of inoculation and washing methods on the efficacy of different sanitizers against Escherichia coli O157: H7 on lettuce. Food Microbiol 19:183-193.

Soni KA, Nannapaneni KA (2010) Bacteriophage significantly reduces Listeria monocytogenes on raw salmon fillet tissue. J Food Prot 73:32-38.

Soni KA, Nannapaneni R, Hagens S (2010) Reduction of Listeria monocytogenes on the surface of fresh channel catfish fillets by bacteriophage Listex P100. Foodborne Pathog Dis 7:427-434.

Taylor AG, Mclauchlin J, Green HT, Macaulay MB, Audurier A (1981) Hospital cross infection with Listeria monocytogenes confirmed by phage typing. Lancet ii:1106.

All the content of the journal, except where otherwise noted, is licensed under a Creative Commons License CC BY-NC. 